\title{
The role of local government in governance and diffusion of Mobility-as-a-Service: exploring the views of MaaS stakeholders in Stockholm
}

Paul Fenton, Gianluca Chimenti and Wisdom Kanda

The self-archived postprint version of this journal article is available at Linköping University Institutional Repository (DiVA):

http:/ / urn.kb.se/ resolve?urn=urn:nbn:se:liu:diva- 165272

N.B.: When citing this work, cite the original publication.

This is an electronic version of an article published in:

Fenton, P., Chimenti, G., Kanda, W., (2020), The role of local government in governance and diffusion of Mobility-as-a-Service: exploring the views of MaaS stakeholders in Stockholm, J ournal of

Environmental Planning and Management. https:// doi.org/ 10.1080/09640568.2020.1740655

Original publication available at:

https:/ / doi.org/ 10.1080/09640568.2020.1740655

Copyright: Taylor \& Francis (Routledge) (STM, Behavioural Science and Public Health Titles)

http:// www.routledge.com/ 


\title{
The role of local government in governance and diffusion of Mobility- as-a-Service: exploring the views of MaaS stakeholders in Stockholm
}

\author{
Authors \\ ${ }^{a}$ Paul Fenton, Environment \& Health Administration, City of Stockholm, Sweden. Email: \\ paul.fenton@stockholm.se \\ ${ }^{b}$ Gianluca Chimenti, Department of Marketing and Strategy, Stockholm School of Economics, Sweden. \\ Email: Gianluca.chimenti@phdstudent.hhs.se \\ ${ }^{c}$ Wisdom Kanda, Environmental Technology and Management, Department of Management and \\ Engineering, Linköping University. Email: wisdom.kanda@liu.se
}

\section{Declaration of interest}

The lead author is the City of Stockholm's Project Manager for the CIVITAS Eccentric project, which is referred to in the article.

\section{Funding}

This study was supported by Horizon 2020 Framework Programme (690699).

\begin{abstract}
Cities around the world constitute an emerging market for Mobility-as-a-Service (MaaS). For local governments, MaaS may offer opportunities to reduce ownership and use of private cars for passenger transport, thereby easing pressures on urban space, the local environment and global climate. By drawing on literature related to socio-technical transitions and the diffusion of environmental innovations, this article analyses survey results of MaaS stakeholders in the City of Stockholm, where several initiatives to facilitate development of MaaS are underway. The results illustrate what stakeholders do and consider important, which kinds of barriers, opportunities and challenges are perceived, and what type of expectations stakeholders share about the role of the City administration in the development of MaaS in Stockholm. In sum, results indicate an important, yet delicate role for local governments in facilitating MaaS, whilst suggesting the need for regional or national regulatory solutions in the longer-term, to ensure legitimacy and transparency.
\end{abstract}

\section{Keywords}

Mobility-as-a-Service (MaaS); local government; governance; diffusion; environmental innovation; Stockholm

\section{Highlights}

- Survey of MaaS stakeholders in the City of Stockholm

- Results show what stakeholders view as important, e.g. expectations about City role

- Engagement of local government viewed as positive by stakeholders

- Regulatory challenges hard to solve at local level

\section{Introduction}

There is widespread consensus among researchers and policy makers that profound changes to current socio-technical systems will be required to achieve a transition to a low-carbon transport system (van Wee and Handy 2016; Perez et al. 2015). Such changes must, for example, influence institutions and the governance of transport infrastructure or systems; support the adoption of new or cleaner technologies or fuels; facilitate emergence of 
alternative modes of transport and support the development of viable business models for new services; and encourage and enable changes in user behaviour (Boons et al. 2013). Thus, such changes need to be systemic, deep-structured and are often called "socio-technical transitions" since they encompass changes in the overall configuration of transportation systems (cf. Geels, 2011).

In many cities, Mobility-as-a-Service (MaaS) has been proposed as a possible means of improving mobility service offerings and thereby facilitate modal shift to more sustainable forms of transportation (Akyelken, Banister and Givoni, 2018; Mulley, 2017). Although there are different definitions and understandings of the concept, in general MaaS may be understood to signify the offering of services that combine different modes of transport into single ticket or subscription packages which enable customers to travel efficiently, thereby removing one possible incentive for car ownership (Kamargianni et al., 2016).

MaaS packages are developed through partnership and interaction between stakeholders that previously worked in isolation or were competitors, as well as new actors (Kamargianni et al., 2016). In theory, the use of ICT applications and improved travel data enables MaaS providers to redefine their service offerings to better match customer requirements (Callegati et al., 2018; Melis et al., 2018). Thus, MaaS offers cities the opportunity to realise various strategic goals, such as improvements in environmental quality, reduction of greenhouse gas emissions, or positive impacts on public health due to increased use of active modes of mobility.

MaaS is emerging as a major topic in current discussions on transport policy (Mulley, 2017), and since MaaS is a nascent phenomenon, the related academic literature is relatively new and emerging (Smith et al., 2018a). Previous research has, among other things, focused on the concept of MaaS itself. Academic contributions have debated what can be considered as MaaS and what cannot (see e.g. Jittrapirom et al., 2017). While some scholars include a wide range of transport services such as peer-to-peer car sharing in the concept (e.g. Holmberg et al., 2016), other scholars narrow down the concept to essentially cover the bundling of transportation services to meet consumer needs (e.g. Kamargianni et al., 2016; Kamargianni and Matyas, 2017).

Furthermore, there have been scholarly contributions on the different types of business models and their viability for the provision of MaaS together with its related development scenarios (Aapaoja et al., 2017; Smith et al., 2018), the market conditions and policies needed to facilitate the uptake of MaaS (e.g. Haahtela and Viitamo, 2017), the implications of MaaS diffusion on natural resources such as land use (e.g. Hensher, 2017) and also the documentation and analysis of several MaaS experiments on-going in different cities worldwide (e.g. Eckhardt et al.,2017).

Other studies investigate formal and informal institutional barriers such as subsidies of public transport, brand and image of public transport, technical maturity of public transport that influence the development and introduction of MaaS (Holmberg et al., 2016). Polydoropoulou et al., (2019) analyzed stakeholders' and end-users' perspectives on different MaaS-related aspects and found that stakeholders are highly motivated to join a MaaS partnership to receive better quality demand data and increase their market shares and revenues, while Application Programming Interfaces (APIs) and the lack of its related data were identified as significant 
technical barriers. Finally, the attachment and reliance of people on their personal cars was identified as the strongest social barrier. Furthermore, some scholars have gone further to evaluate the design of MaaS projects in real life. For example, Karlsson et al., 2016 identified that key service attributes such as simplicity, improved access and flexibility, convenience, and economy are important success factors for the design and implementation of MaaS. Jittrapirom, et al., (2018) proposed an adaptive policy process, which allows policymakers to create policies to tackle the uncertainties that surround the development of Maas such as technological feasibility, future demand and willingness of crucial stakeholders to cooperate.

Despite these previous scholarly contributions, it remains unclear as to what role cities should have in the governing of MaaS. Specifically, research on the governance of Maas is underdeveloped and consistently pointed out as an important research gap which needs to be addressed (Pangbourne et al., 2020). For example, should cities play an active role in facilitating or implementing MaaS services? Should cities play a passive role and wait until MaaS services appear on the local market? These two questions illustrate the possibility for divergent approaches in the governing of MaaS at the local level. Moreover, these questions imply that the emergence of MaaS also has relevance for other levels of government, along with a diverse range of local stakeholders, including mobility providers and users (cf. Hirschhorn et al., 2020). The implementation of MaaS is thus related to, influenced by, and affects, a diverse range of wider themes including, for example, sustainable transportation, urban planning and the use of public space, social inclusion, and the vast literature on ICT and product-service systems.

Against this background, this article focuses more narrowly on two important aspects of MaaS that have not been extensively discussed in past literature. First, current literature on the governance of MaaS explores the role of key stakeholders in defining implementation and practice, yet often takes for granted or neglects discussion of the (real or potential) role of local governments in governing MaaS (and which is identified as a barrier to development of MaaS in Smith et al., 2018a; Smith et al., 2018b).

For this reason, this paper considers how stakeholders view the role of local governments in facilitating or implementing MaaS, and the implications of such views for local governments. In Stockholm, Sweden, several initiatives are underway aiming to implement MaaS services in the near future. This article explores the views of MaaS stakeholders in Stockholm about the ongoing development of MaaS in the city, employing data from an exploratory survey to identify critical issues, barriers to and opportunities for the implementation of MaaS. This survey considers whether system-level challenges; actor-level challenges; and business aspects exert important influences on the diffusion and upscaling of MaaS as a niche activity to become mainstream and break into the existing regime for transportation. Does the example of Stockholm indicate the presence of such influences? If so, what does this tell us about Maas in Stockholm and other contexts? And what can we learn about the role of local governments in governing MaaS?

The second topic addressed by the article concerns the diffusion and uptake of MaaS as an innovation with potential environmental benefits. The authors argue that MaaS can be considered a nice level innovation with environmental benefits as the bundling of various types of travel service into a single MaaS package is expected to result in (or are developed with the intention for) environmental improvements in terms of e.g. reduced ownership or use of 
private cars, increased use of sustainable transport modes, possibility to introduce electric or alternatively-fueled vehicles to MaaS services, etc.

By addressing these perspectives and research questions, this paper contributes directly to MaaS implementation processes and to policy debates concerning MaaS. The paper proceeds with a discussion of the Theoretical Background concerning MaaS and socio-technical transitions, followed by diffusion of niche level environmental innovations, before presentation of the case of Stockholm and the Methods used to conduct the study. The Results of the survey are then presented and then analysed in a Discussion which informs concise Conclusions about the development of MaaS in Stockholm and other locations.

\section{Theoretical background}

This section presents theories that can be used to analyze the role of the local government in the governance of MaaS and also the uptake and diffusion of MaaS as a niche level environmental innovation. First, we present the emergence and upscale of MaaS as a sociotechnical transition using the multi-level perspective (MLP) on transitions. We then present the governance of MaaS systems as giving direction to this socio-technical change. Finally, the upscale and diffusion of MaaS is presented from the perspective of a niche level environmental innovation seeking to become mainstream and break into the existing transportation regime.

\subsection{MaaS and socio-technical transitions}

The multi-level perspective (MLP) on sustainability transitions is a relevant starting point to explore how innovations such as MaaS can be conceptualized as a socio-technical system, and how they emerge and break into mainstream socio-economic systems (Docherty et al., 2018). The MLP conceptualizes that transitions occur due to interactions between three levels of societal structuration over time - landscapes, regimes and niches. The landscape is the macrolevel of the economy and incorporates external forces such as global oil prices, climate change, economic recession which put pressure on the regime but cannot be directly controlled by governments (Smith, Voß and Grin, 2010).

The regime on the other hand represents the meso-level of structuration and evolves to address societal needs such as transportation. Due to its co-evolutionary nature, the regime is characterized by technological lock-ins, path dependencies and dynamic interactions whereby well-established technological systems become deeply intertwined with culture and lifestyles and resistant to change (Geels, 2011). The regime in this context can consist of technology (e.g. cars, traffic lighting systems), infrastructure (e.g. harbors, roads, rails), as well as other influences such as knowledge, markets, user practices, cultural and symbolic meanings.

Essentially, the MLP postulates that the regime can be reconfigured over time by external pressures coming from the landscape and also niche innovations. Farla et al., (2012) suggest that the biggest challenges in achieving sustainability transition lies in changing the momentum of incumbent unsustainable socio-technical systems, the pace at which such systems and their alignments develop and also the direction. Niche innovations sit at the micro-level of structuration and these innovations emerge under protected spaces to fundamentally 
challenge the prevailing way society addresses its needs for e.g. energy, transport and food (Kemp et al., 1998).

Niche innovations are often considered disruptive and outsiders by actors within the regime. However, for niche innovations to scale up and eventually become mainstream, there is the need for buy-in from actors within the regime (Verbong, Geels and Raven, 2008; cf. Hirschhorn et al., 2020, and Smith et al. 2020). This systemic conceptualization of the transition to MaaS systems helps us to understand why such a change can be difficult and an essential issue for governance. Is it not simply an engineering or ICT challenge but rather a challenge related to a dynamic set of actors, networks and institutions interacting with each other over time. Thus, while the dominant approach to providing transportation for several decades has been through silo solutions, advancements in information communication technology provide possibilities for breaking the path dependency and rigidity of this regime and provide bundled mobility services which are more sustainable.

\subsection{Mobility-as-a-Service and Governance}

While the MLP is a useful analytical framework for analyzing the dynamics of transitions, it has also received certain criticisms (for an overview see Geels, 2011). For this article and with its focus on the governance of MaaS, a particularly relevant critique of the MLP is its lack of attention to agency in transitions. In particular, scholars interested in the governance of sociotechnical transitions argue for more attention to the role of politics and power struggles in transitions (e.g. Smith et al, 2005). Governance has been conceptualized and defined differently by scholars as a reflection of its changing role and nature in society. Rhodes (2007) argues that, the task of modern-day governance can be understood as the expression of set of beliefs, practices, traditions, and dilemmas that are negotiated through inclusive dialogue and deliberation.

Van der Heijden (2014), defines governance as an intended activity undertaken by one or several actors seeking to shape, regulate human behavior in order to achieve a desired collective goal. Governance is particularly relevant in sustainability transitions since governance in the form of state involvement through regulations, taxes, subsidies and support has been identified as particularly important in sustainability transitions and in the diffusion and upscaling of environmental innovations due to the presence of externalities and also the need to coordinate different stakeholders (Kanda et al., 2016) and change existing economic frame conditions (Geels, 2011).

Thus, Smith et al. (2005) argue that managing transitions requires continuous adaptation in the prevailing system of governance to changing circumstances in order to articulate what needs to be done, related policy interventions, applying relevant resources and follow-up actions. Similarly, Loorbach (2010) highlights the need to undertake experiments, monitor and evaluate these experiments, and adjust the visions, expectations and collective goals. In this regard, the role of governance in transitions is to provide a both a normative (to develop a set of goals for the outcomes of the transition) and cognitive direction (i.e. framing the problem) for the wider transition and deploy resources to that effect. In doing so, the state has shifted from one of public administration of provided services, through a phase of public management where the focus has been on the coordination of public services provided by a range of actors, to ensuring 
the capturing of public value in contemporary patterns of public service provision (Docherty, 2018).

\subsection{Diffusion of environmental innovations - which issues may influence the development of Maas?}

This section briefly reviews literature on factors that influence the diffusion and scale up of niche level environmental innovations in general (including MaaS). Characterizing MaaS as an environmental innovation can be contested. Though an evaluation of the environmental benefits of MaaS is not the focus of this paper, a critical reflection on the environmental benefits of developing and adopting MaaS is relevant. In principle, a defining characteristic of environmental innovations is their potential environmental benefits with or without prior intention (del Río et al., 2016). A challenge with the operationalization of this understanding in the context of MaaS is that, in practice, concluding on which technologies actually reduce environmental impacts is challenging and does not always yield objective and unequivocal results due to contextual issues such as types of impacts assessed, quality of data, methodological choices and uncertainty (cf. Finnveden, 2000). Mobility-as-a-service can be argued as an environmental innovation since it is envisaged as offering environmental benefits when compared to existing or alternative solutions such as the use of private cars.

To identify factors that influence the diffusion of environmental innovations including MaaS, we reviewed different strands of literature including the diffusion of innovations literature (Rogers, 2003) and the diffusion of environmental innovation literature (e.g Kanda, 2017; Mejía-Dugand et al., 2013). The diffusion of innovations literature is dominated by analysis of the individual characteristics of adopters (e.g. their innovativeness and risk aversion) which determines their eagerness to adopt or reject an innovation. On the other hand, the environmental innovation diffusion literature has among other things emphasized the innovation characteristics such as externalities and free rider problems, the importance of regulations and their potential environmental benefits as particularly influential characteristics in their diffusion (del Río et al., 2016; Rennings, 2000).

Environmental technologies including services - also known by myriad synonyms including "cleantech" and "low-carbon technology" - are defined by the promise of or realized environmental improvements either in terms of a specific action or from a life-cycle perspective (Carrillo-Hermosilla, Del Río, and Könnölä, 2010; Fenton and Kanda, 2017). The emergence of promising environmental technologies and services is thus of interest to stakeholders seeking to address themes such as urban sustainability or sustainable transportation, and can be observed in the diverse literature addressing the environmental impacts of e.g. electric vehicles and e-mobility, public transport, car-sharing or ride-sharing, last-mile urban logistics, waterborne transport, multimodal or intermodal solutions.

From this perspective, MaaS should be of interest to a wide range of stakeholders, including municipal planners and politicians, with interest in sustainable urban development. However, for MaaS to "emerge" as a mainstream environmental technology or service, the concept must be developed, operationalized and diffused both within contexts (i.e. the emergence of pilot services followed by rival, competing services), and then between contexts (i.e. in multiple 
locations). The diffusion of MaaS as an environmental technology or service is thus of interest both at the location of a MaaS experiment, and in terms of how that particular MaaS experiment feeds into a wider transition towards MaaS in multiple locations.

Kemp and Volpi (2008) describe diffusion as being an aggregated decision by potential adopters to make use of a technology or service, which is influenced by many factors over varying time intervals. Fenton and Kanda (2017) identify various strands in the review of literature on diffusion, summarized below, of which three strands are assessed in this study and described in Table 1 (adapted from Fenton and Kanda, 2017).

- Innovation characteristics largely comprise dynamic aspects which affect the ease of adopting innovation into ongoing market practices, including perceptions concerning both social and material aspects (Rogers, 2003; Beise and Rennings, 2005).

- System-level factors pertain to macro issues concerning market saturation, physical and non-physical networks, formal and informal institutions, but also the degree of technological advancements in the economy at large (Mignon and Bergek, 2016).

- Actor-level characteristics, which relate to specific actor-level challenges which influence - and are influenced by - the wider context of the system (Mignon and Bergek, 2016).

- Business aspects, finally, emphasize the roles of market actors with respect to collaborations, distribution of responsibility or compliance with relevant regulatory frameworks (Kanda et al., 2015).

Table 1. Overview of factors influencing diffusion of environmental technologies (adapted from Fenton and Kanda, 2017).

\begin{tabular}{|c|c|c|}
\hline \multicolumn{2}{|c|}{$\begin{array}{l}\text { Factors influencing diffusion of environmental } \\
\text { innovations }\end{array}$} & \multirow{2}{*}{$\begin{array}{l}\text { Description } \\
\text { Market organisation, structure, ease of entry. }\end{array}$} \\
\hline System-level factors & \begin{tabular}{|l} 
Market structure \\
challenges
\end{tabular} & \\
\hline & $\begin{array}{l}\text { Infrastructure } \\
\text { challenges }\end{array}$ & $\begin{array}{l}\text { Physical and non-physical infrastructure needed } \\
\text { for market to function. }\end{array}$ \\
\hline & Financial challenges & Investment or operational costs, etc. \\
\hline & Institutional challenges & $\begin{array}{l}\text { Formal or informal rules, norms etc. favouring } \\
\text { conventional practices. }\end{array}$ \\
\hline & Interaction challenges & $\begin{array}{l}\text { Degree, strength and impact of interaction, } \\
\text { including potential lock-in/out effects. }\end{array}$ \\
\hline \multirow[t]{3}{*}{$\begin{array}{l}\text { Actor-level } \\
\text { characteristics }\end{array}$} & $\begin{array}{l}\text { Technology supply } \\
\text { challenges }\end{array}$ & $\begin{array}{l}\text { Lack of capacity, competence, resources on } \\
\text { supply side that impedes implementation. }\end{array}$ \\
\hline & $\begin{array}{l}\text { Adopter resource } \\
\text { challenges }\end{array}$ & $\begin{array}{l}\text { Factors, e.g. limited resources, impeding } \\
\text { adoption. }\end{array}$ \\
\hline & Behavioural challenges & $\begin{array}{l}\text { Norms, values etc. influencing investment } \\
\text { decisions and adoption. }\end{array}$ \\
\hline \multirow{2}{*}{$\begin{array}{l}\text { Business aspects } \\
\text { (influenced by the } \\
\text { innovation } \\
\text { characteristics) }\end{array}$} & $\begin{array}{l}\text { Market (including } \\
\text { regulation) }\end{array}$ & $\begin{array}{l}\text { The system of exchange through which } \\
\text { producers and customers interact. }\end{array}$ \\
\hline & Finance & $\begin{array}{l}\text { Including costs of development, } \\
\text { implementation and revenues obtained. }\end{array}$ \\
\hline
\end{tabular}




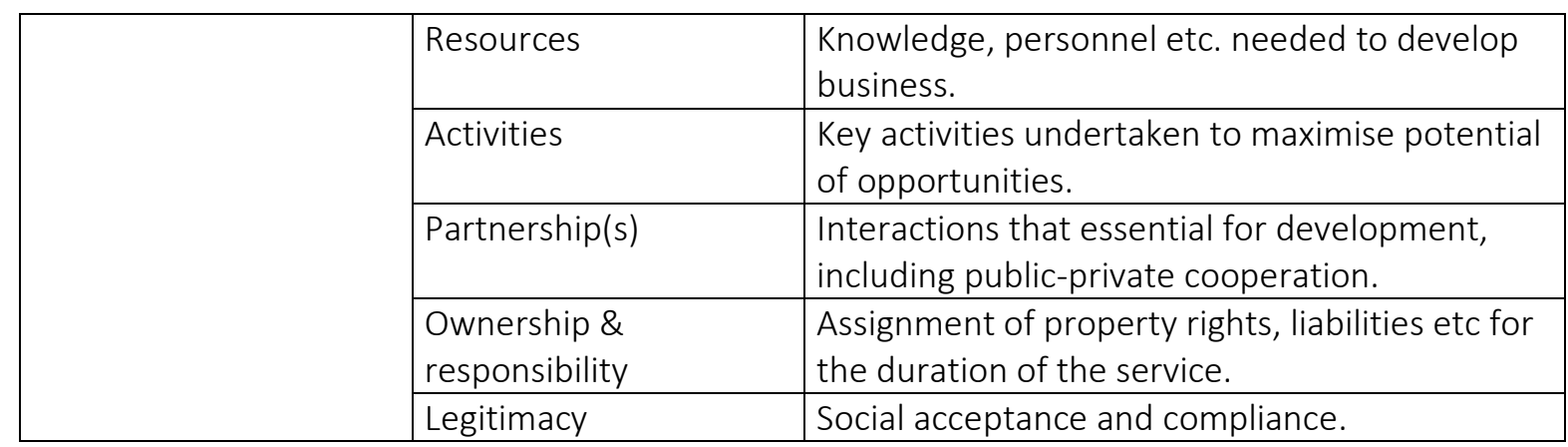

In this study, the extent to which such factors and challenges influence the diffusion of MaaS are explored with reference to the case of Stockholm, Sweden. Each of these three aggregation levels of factors (i.e. system-level characteristics, actor-level characteristics and business aspects) are considered in this paper by including corresponding relevant questions in the survey. As MaaS projects are emerging in a wide range of contexts, the authors have chosen to focus on a specific location to gather data, whilst adopting an approach which may be transferable or may indicate results relevant to MaaS in locations other than Stockholm. While we have adopted the above set of factors to have a systematic approach to our analysis, there are also contributions which synthesize factors influencing specifically the development and implementation of MaaS. For example, based on empirical studies in Budapest and Greater Manchester, Polydoropoulou et al. (2019, cf. Polydoropoulou et al. 2020) synthesize a set of social, financial, institutional and technical factors that influence the development and implementation of MaaS. In addition, Jittrapirom et al. (2017) synthesize a diversity in attributes, such as personalization, customization, tariff options and platform aggregators that can be used to characterize MaaS and also influence its development and implementation. Finally, the factors from these different strands of literature share several similarities but also differences depending at their level of aggregation which should be well noted when reading and interpreting results from this study. In the following section, we provide a brief overview of the Stockholm case and several ongoing MaaS initiatives.

\subsection{Case selection - Sweden and the City of Stockholm}

Historically, Sweden was among the early adopters of the MaaS concept and two initiatives have been particularly influential in framing national and international MaaS debates.

Samtrafiken was founded in 1993 as an initiative for combining various modes of public transport (e.g. combining bus and tram tickets) and for the implementation of a national ticketing and payment standard. Owned by 37 public and private organisations, Samtrafiken represents a hybrid forum for transportation stakeholders including rail and bus operators, car sharing platforms and local transport authorities (Smith et al, 2020). In recent years, Samtrafiken has focused increasingly on developing a dedicated platform for MaaS and identifies the need "to enable and promote combined mobility services on a large scale [...] via a national access point and ensure a common regulatory framework" (Samtrafiken, 2019).

This implies a shift in Samtrafiken's role towards being an active instigator, rather than merely offering auxiliary mobility solutions (e.g. ticketing, scheduling). Samtrafiken has also launched an internal taskforce dedicated to the technical aspects required for MaaS platforms. A sub- 
division called Trafiklab has been established to gather large data sets, such as user travel behaviour or car sharing transactions, to make these available for a digital MaaS app. However, this work is complicated due to diverging interests and problems with the use and standardisation of data (see also Table 2).

The second example is provided by Ubigo. Between 2012-2014, the Swedish innovation agency VINNOVA funded projects aimed at encouraging sustainable urban mobility. One such project was the UBIGO-initiative involving around 70 households in Gothenburg. The initial UBIGO test phase spanned over a 6-month period and included various modes of mobility, ranging from car sharing via public transport to bike sharing (see Smith et al, 2018b; Strömberg et al, 2016). The pilot was awarded the 'Promising Innovation in Transport Award' by the International Transport Forum in 2015 (ITF, 2015). Despite its success among users, the service was shut down after the procurement was terminated, largely due to diverging political interests between stakeholders (Smith et al.,2018b).

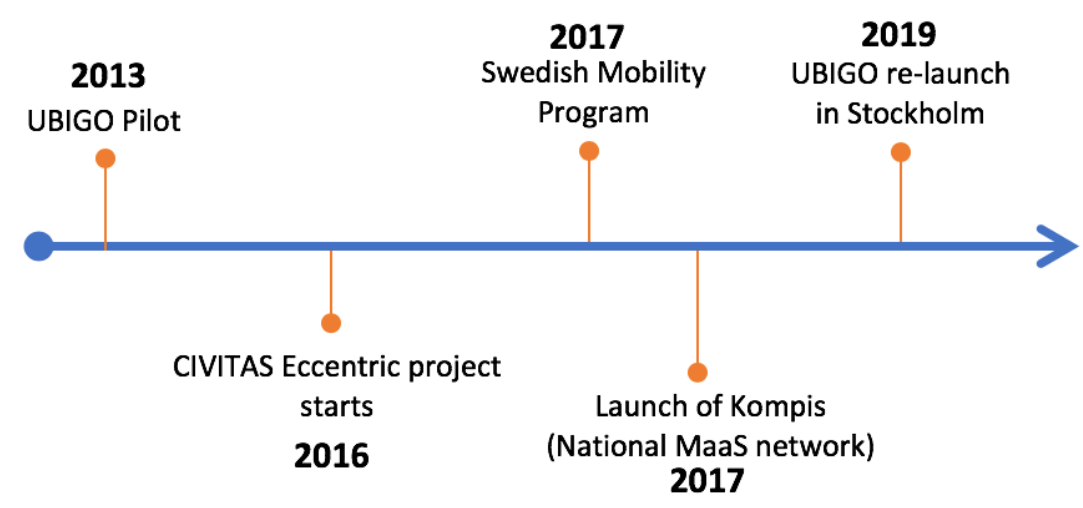

Figure 1: Timeline of key MaaS milestones in Sweden.

This initial attempt to realize MaaS in Sweden has been followed by various efforts to foster MaaS, including the relaunch of the Ubigo service in Stockholm (CIVITAS Eccentric, 2019; see also Table 2). The creation of new public-private networks has led to a dense ecosystem dedicated to sustainable means of transportation and MaaS. Indeed, the potential development of MaaS services complements a range of other national and local policies addressing inter alia decarbonisation, fossil-fuel free transportation, and the advancement of the shared economy (e.g. City of Stockholm, 2016).

The City of Stockholm (population approx. 950,000), like many other municipalities in Sweden, attempts to use its strategic and physical planning to influence patterns of transportation in the City and promote sustainable mobility (Hrelja, Hjerpe, and Storbjörk 2015; Hysing, Frändberg, and Vilhelmson 2015). However, as one of 26 municipalities in the Greater Stockholm region (population approx. 2.3 million) and with the regional County Council responsible for coordination and procurement of public transport services, the City of Stockholm often needs to collaborate with a wide range of stakeholders, both public and private, to achieve its strategic objectives (Paulsson, Hylander and Hrelja, 2017; cf. Isaksson, Antonson and Eriksson, 2017).

In light of this complex environment, the emergence of several initiatives aiming to facilitate demonstration of MaaS in Stockholm offers an opportunity to assess the views of stakeholders concerning barriers and opportunities to Maas (see Table 2). 

Table 2. Examples of ongoing MaaS initiatives in Stockholm. Related initiatives include corporate services for employees, such as ScaniaGo. Sources: websites of the named initiatives/organisations.

\begin{tabular}{|c|c|c|c|c|}
\hline Initiative & What is it? & Main purpose & Indicative actions & Funders \\
\hline DriveSweden & $\begin{array}{l}\text { Strategic research hub } \\
\text { involving cross-sector } \\
\text { collaborations supporting } \\
\text { and orchestrating } \\
\text { transformative mobility } \\
\text { initiatives }\end{array}$ & $\begin{array}{l}\text { To establish and streamline } \\
\text { connected, autonomous } \\
\text { and shared mobility }\end{array}$ & $\begin{array}{l}\text { KOMPIS, data driven policy } \\
\text { development, cloud services for } \\
\text { traffic data sharing (e.g. } \\
\text { allowing vehicle and fleet } \\
\text { tracking) }\end{array}$ & $\begin{array}{c}\text { Vinnova, Swedish Energy } \\
\text { Agency, Formas }\end{array}$ \\
\hline KOMPIS & $\begin{array}{l}\text { Project involving academics, } \\
\text { practitioners and } \\
\text { consultants examining } \\
\text { opportunities for combined } \\
\text { mobility (MaaS) }\end{array}$ & $\begin{array}{l}\text { To create strategic action } \\
\text { plans for MaaS } \\
\text { developments in Sweden }\end{array}$ & $\begin{array}{c}\text { MaaS roadmap from 2017-2027 } \\
\text { (http://kompis.toda } \\
\text { y/fardplanen/) }\end{array}$ & $\begin{array}{l}\text { Platform within } \\
\text { DriveSweden }\end{array}$ \\
\hline Samtrafiken & $\begin{array}{l}\text { B2B marketplace for actors } \\
\text { within the public } \\
\text { transportation sector } \\
\text { facilitating cross-pollination } \\
\text { of knowledge, innovative } \\
\text { practices, etc. }\end{array}$ & $\begin{array}{l}\text { To co-ordinate joint } \\
\text { business agreements and } \\
\text { establish a national } \\
\text { coordination platform for } \\
\text { stakeholders to co-create } \\
\text { new MaaS initiatives }\end{array}$ & $\begin{array}{l}\text { Swedish Mobility Program } \\
\text { (SMP), Resplus, Trafiklab, } \\
\text { Resrobot, Physical co-working } \\
\text { places for actors in the industry }\end{array}$ & $\begin{array}{l}\text { A variety of public and } \\
\text { private stakeholders, } \\
\text { including transportation } \\
\text { providers (e.g. SJ, } \\
\text { Nobina) }\end{array}$ \\
\hline $\begin{array}{l}\text { Civitas } \\
\text { Eccentric }\end{array}$ & $\begin{array}{l}\text { EU project involving five } \\
\text { cities aiming to } \\
\text { demonstrate innovative } \\
\text { solutions for sustainable } \\
\text { mobility, including MaaS }\end{array}$ & $\begin{array}{c}\text { To establish, demonstrate } \\
\text { and evaluate a MaaS pilot } \\
\text { in Stockholm during the } \\
\text { period 2016-2020. Ubigo } \\
\text { launched this service in } \\
2019 \text {. } \\
\end{array}$ & $\begin{array}{l}\text { Facilitation of stakeholder } \\
\text { meetings, development costs, } \\
\text { information campaigns, } \\
\text { evaluation of pilot }\end{array}$ & $\begin{array}{l}\text { European Union's } \\
\text { Horizon } 2020 \text { research } \\
\text { and innovation } \\
\text { programme under grant } \\
\text { agreement No } 690699\end{array}$ \\
\hline $\begin{array}{l}\text { National } \\
\text { MaaS project }\end{array}$ & $\begin{array}{l}\text { International competition } \\
\text { for innovative MaaS } \\
\text { solutions }\end{array}$ & $\begin{array}{l}\text { Develop, initiate and } \\
\text { contribute to emergence of } \\
\text { new MaaS packages and }\end{array}$ & $\begin{array}{l}\text { Innovation procurement } \\
\text { followed by pilot } \\
\text { demonstrations and evaluation }\end{array}$ & $\begin{array}{l}\text { A Challenge from } \\
\text { Sweden (Swedish Energy } \\
\text { Agency in cooperation }\end{array}$ \\
\hline
\end{tabular}




\section{Methods}

This paper presents findings from an exploratory survey of professionals working in public administration, companies, academia and non-governmental organisations on the topic of MaaS in the Stockholm region, Sweden. These professionals were identified by the researchers as "stakeholders" in the development of MaaS in Stockholm using internet searches and as "key informants" in discussions with an expert working at the City of Stockholm. For example, individuals representing each of the initiatives described in Table 2 were invited to respond.

Yin (2009) considers surveys as an appropriate method for exploratory studies of particular kinds of questions. Furthermore, research methods including survey methods, as well as focus groups, workshops and interviews have already been used by other researchers to study the development and implementation of MaaS (e.g. Polydoropoulou et al. (2019). Internet survey tools are considered to provide a quick and easy format for recipients to use (Bryman, 2015). As many of the MaaS initiatives in Stockholm are at an early, dynamic stage, the authors felt that a survey was the most appropriate method for gathering general data about the views of stakeholders. Other methods, such as focus groups, were considered, but limited resources and time, combined with the aforementioned challenge of identifying possible respondents, meant that this possibility was discounted. Individual or groups interviews could be a possibility for future studies, once the initiatives have advanced more from planning to demonstration and as MaaS gains momentum.

In this study, data was collected using an internet survey tool during a two-week period in May 2018. The stakeholders identified as "key informants" received the survey via email along with a brief introduction to the study. A reminder was sent after one week to those individuals that had not completed the survey. All responses were anonymous, although respondents were asked to provide an email address in case they wish to be contacted in the future.

\subsection{Survey structure}

The survey included ten questions, the last of which concerned the possibility for future contact with the researchers. Questions 1-3 concerned the respondents' organisation and perceptions about the role of their organisation in the development of MaaS in Stockholm. Questions 4-6 concerned the type of issues stakeholders work on, view as important to work on, and views as barriers or opportunities to the development of Combined Mobility / MaaS in Stockholm. Questions 4-5 refer to factors influencing the diffusion of niche level environmental innovations identified as "Business aspects" in Fenton and Kanda (2017) (see Table 1) whereas Question 6 refers to "System-level challenges" in the same table.

Questions 7-8 address respondents' view as to what extent the City of Stockholm should be involved in development of MaaS in Stockholm and which kind of factors the City may have a role in influencing. Like Questions 4-5, Question 8 is framed with reference to "Business Aspects" and the results of these questions, whilst not directly comparable, offer complementary insights into the ways respondents view their own work, issues they consider important to address, and the potential role of the City is addressing some of these issues. Finally, Question 9 concerns the general perceptions of stakeholders about "Actor-level 
challenges" in the diffusion of MaaS as a niche level environmental innovation. See table in the appendix presenting the survey questions (as they were presented to the survey participants) as well as the factors adopted from Fenton and Kanda (2017).

\subsection{Limitations}

As an exploratory study, the survey questions were designed to follow a simple format whilst broadly mirroring the different kinds of challenges and factors influencing diffusion of environmental innovations. Responding to the survey questions mainly involved selecting single answers per question or category on a scale. There were no questions that involved ranking between categories or more complicated tasks. However, it is possible that some respondents misunderstood categories or considered the terminology used in the survey to be confusing. We received no such feedback, and as all respondents completed the survey and almost all completed all questions in full, we assume this was not the case. In addition, most questions contained an opportunity to add remarks or clarifications in a field "Other: please provide a comment", which some respondents used.

Nonetheless, it is important to state that the results of this study should be considered indicative. The results offer an insight into stakeholder perceptions concerning the current, rapidly changing and emerging market for MaaS in Stockholm as it is developing; at a later stage, it may be possible to conduct a more comprehensive analysis about the respective success or failure of ongoing initiatives, or indeed to assess the merits of this study and its analysis.

\section{Results}

The survey was sent to 57 recipients via email and posted on the lead author's linkedin page with a message encouraging MaaS stakeholders in Stockholm to complete it. As noted in Methods, the 57 recipients were identified following discussions with representatives from ongoing initiatives and the City of Stockholm, and, in general terms, represented private companies offering mobility services, researchers working on MaaS, and other actors such as public sector organisations. It should be noted that the authors did not prioritise distribution to municipal representatives, precisely for the reason that we aimed to study the views of stakeholders about the role of local governments, rather than the views of local governments about their own role. The views of local government representatives could easily be explored in another study using additional methods such as focus groups.

In total, 24 people completed the survey, 22 of which had received it by email, giving a $38.6 \%$ response rate. An additional two individuals accessed the survey via linkedin. All 24 respondents completed the survey, although not all respondents answered all parts of each question. However, the response and completion rates suggest that the authors were reasonably successful in identifying MaaS stakeholders in Stockholm, with the responses and results indicating these individuals shared that view and identify themselves as MaaS stakeholders. 


\subsection{The organisations and roles of respondents}

In the first question, the respondents were asked about the type of organisation the respondents work for. There is a degree of overlap between the pre-defined alternatives, yet these categories illustrate the different kinds of stakeholders working on MaaS in Stockholm.

Seventeen of the respondents (70.8\%) identified themselves as working for companies (e.g. transport, ICT, consultancy), with $12.5 \%$ (3 respondents) working in research and the remainder $16.7 \%$ (4 respondents) working for municipalities, government departments or agencies, or for other types of organisation. In questions two and three, respondents were asked how large or small they consider their organisation's role to be in the development of MaaS in Stockholm and whether they consider their organisation to play an important role in the development of MaaS in Stockholm. All respondents considered themselves to have a role (from little to large) and also played an important role (from sometimes important to key role) in the development of MaaS in Stockholm. This response from the participant companies regarding their roles and also activities gives weight to their perception about the development of MaaS in Stockholm. Specifically, all of the respondents viewed themselves and/or their organisations as having a role in the development of MaaS in Stockholm, with 11 of the 24 respondents claiming a large role, and 13 claiming smaller roles. When assessing the importance of these roles, there was a slight shift in the responses towards importance, meaning that some of the respondents claiming a small role view that role as sometimes or often important or even essential.

\subsection{Organizational roles, barriers and opportunities to Maas?}

Questions 4-6 aimed to identify the issues stakeholders work on, the issues they consider important, and which type of issues stakeholders consider to pose barriers or present opportunities to the development of MaaS in Stockholm. Respondents were offered a series of pre-defined alternatives based on the theoretical factors influencing diffusion of niche level environmental innovations (see Table 1), and could identify additional issues in separate comments. Figures 2-5 illustrate the responses to these questions, minus a small number of "Don't know" responses.

The responses to Question 4 indicate a number of issues that stakeholders often or almost always work on (see Figure 2). These include cooperation and partnerships with other stakeholders, resources (knowledge, people etc.), responsibility and legitimacy. From Figure 2, it is clear that only a few respondents focus solely on a specific issue. For examples, only up to $5 \%$ of the respondents focused solely on market structure, resources, cooperation and partnerships, and responsibility issues while up to $10 \%$ of focused solely on building legitimacy for MaaS. Furthermore, It is also clear from the results that the respondents regularly (often and almost always) work on a combination of activities related to MaaS development (i.e. from market structure, regulation, resources, cooperation and partnerships, responsibilities and legitimacy). Finally, it is also evident that the issue of cooperation and partnerships was the activity that all the respondents engaged in and also largely perceived as their regular role (often and almost always). This is perhaps no surprise in a developing market, as stakeholders work to for example establish networks and engage other stakeholders, gain credibility and build trust, and identify individuals or groups who can work to develop the market. The more 
complex issues concerning how markets should work and be regulated, who should pay, and so on, emerge only if and when there is a demonstrable need to define or clarify the basis for transactions, rights and responsibilities, etc.

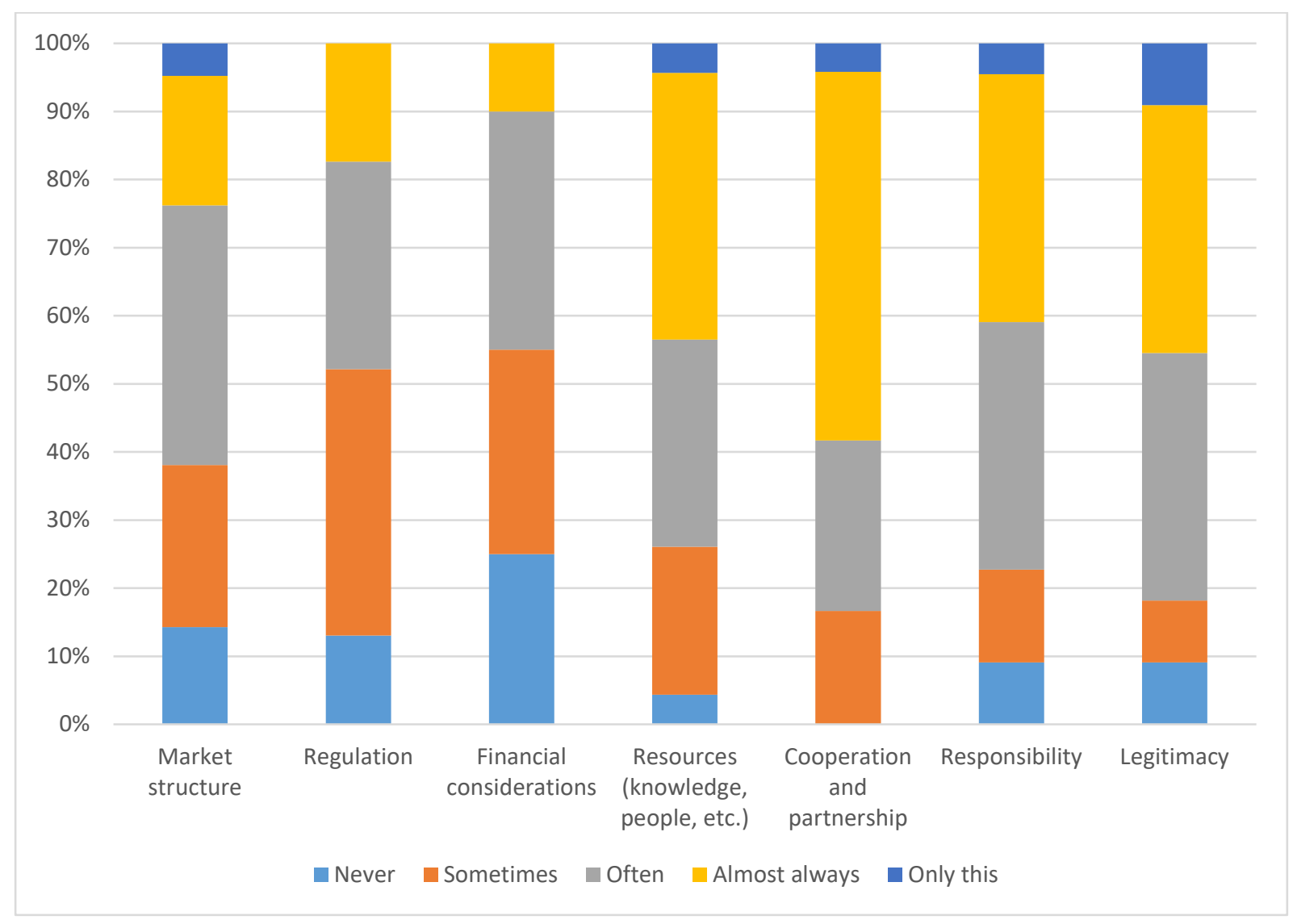

Figure 2. Responses to Question 4: "Which of these issues do you/your organisation work on to support the development of Combined Mobility / MaaS in Stockholm?"

Turning to Question 5, when asked which issues the respondent or their organisation considers are important to the development of MaaS in Stockholm. The most important issue was cooperation and partnerships for the development of MaaS, followed by building legitimacy (social acceptance and the compliance with formal institutions), and then responsibility, financial considerations, market structure all the way to regulation. 


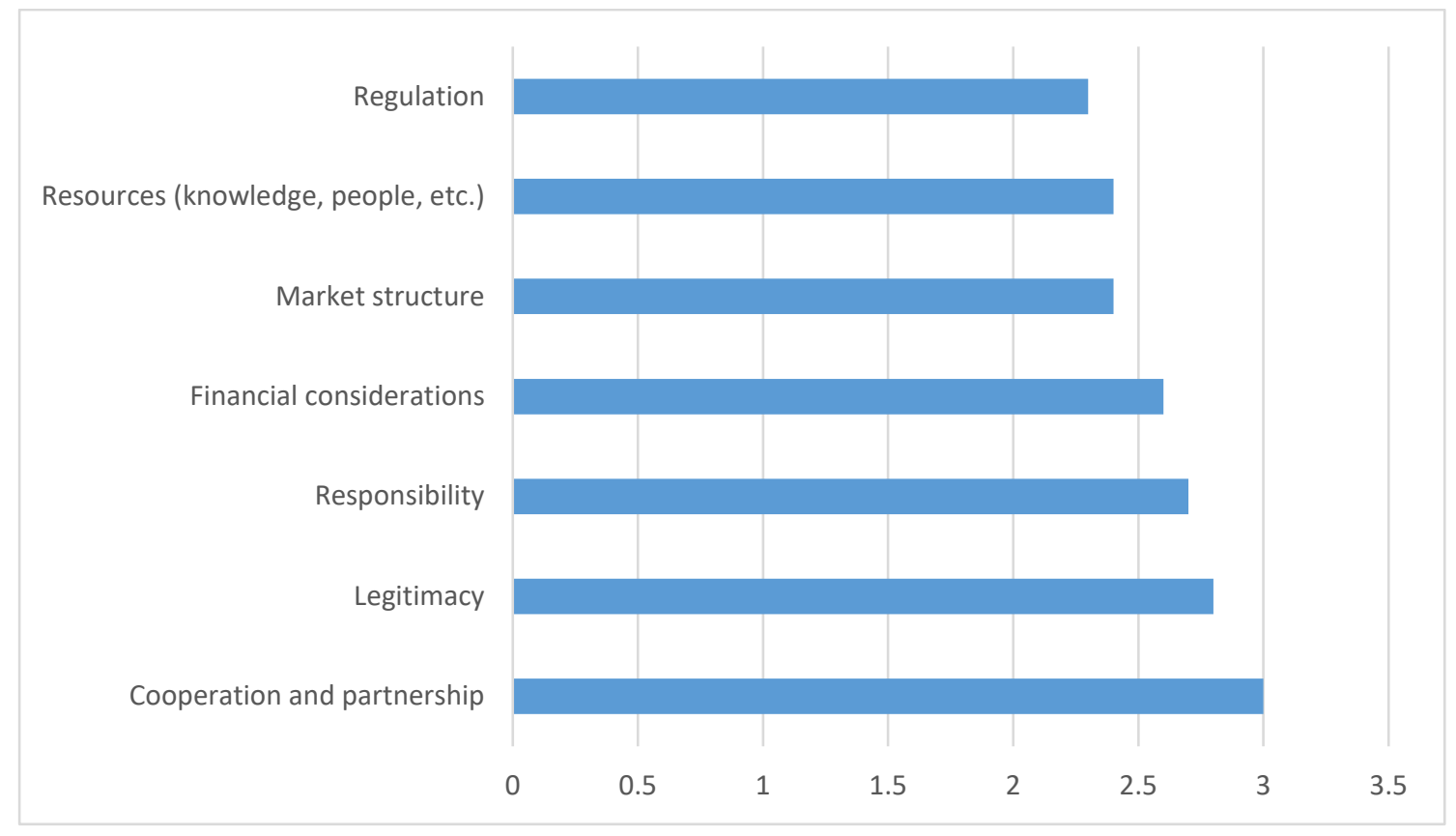

Figure 3. Responses to Question 5: "Which of these issues do you/your organisation consider important for the development of Combined Mobility / MaaS in Stockholm?" (Scale of 0=Not important, 1=Slightly important, 2=Moderately important, 3=Important, 4=Very important)

Irrespective of the ranking associated to the different factors, the respondents considered the issues they worked with to be at least moderately important i.e. scoring an average above 2 for the development of MaaS. An interesting observation is the relatively lower importance associated with issues such as market structure and regulation which have been identified in previous literature as fundamental in market formation for niche environmental innovations due to their competition against other established innovations.

This issue can be directly related to the mandate and resources of the identified actors. If such actors do not have the financial and personnel resources and even mandate to deal with systemic issues such as market structure and regulation, they may limit their activities to issues such as fostering partnerships and cooperation among the various actors relevant for the development of MaaS in Stockholm. Another possibility is that key actors working with issues such as developing the market structure and also issues such as regulations were not identified and included in this study.

In contrast to Questions 4-5, Question 6 focused on "System-level challenges", with responses providing indications as to the presence or absence of barriers and opportunities for the development of MaaS in Stockholm. Figure 4 shows the results (excluding "Don't knows"), which suggest market structure, physical infrastructure, institutional aspects, and regulations are generally perceived as barriers to development of MaaS in Stockholm. 


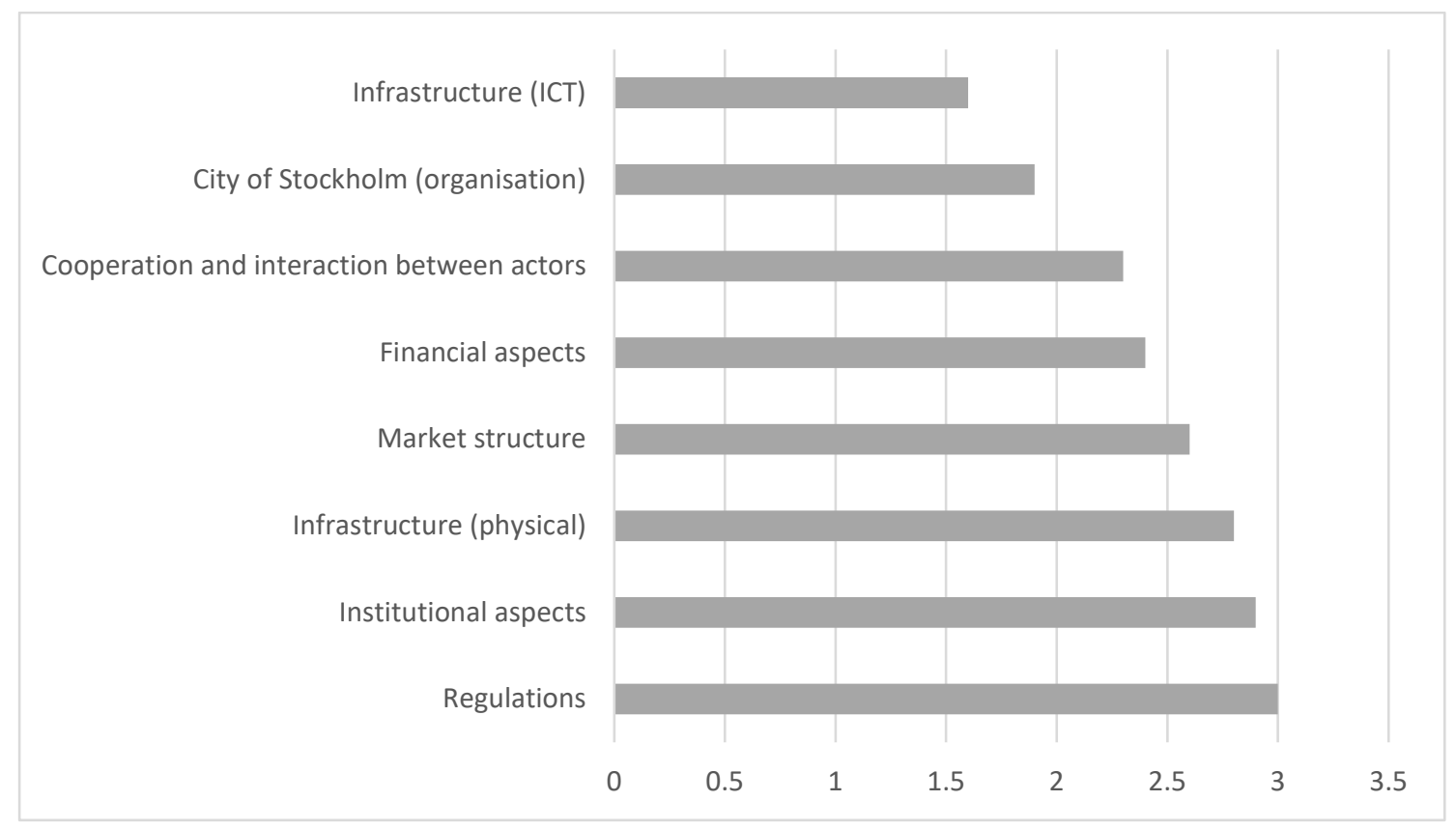

Figure 4. Responses to Question 6: "Do you consider... as a barrier to or opportunity for the development of Combined Mobility / MaaS in Stockholm?" (Scale of 0=not a barrier, 1=Slight barrier, 2=Moderate barrier, 3=barrier, 4=Large barrier)

ICT infrastructure is perceived more favourably with an average value less than 2 (i.e. close to a slight barrier), whereas regulation and institutional aspects were ranked as the highest barriers with average values above 2.5 (i.e. close to barriers). Other factors such as the organization of the city of Stockholm, cooperation and interaction, financial aspects and market structure were perceived as close to moderate barriers. The results could be interpreted as being reflective of real barriers and opportunities in an emerging market. However, the identification of so many barriers (real or perceived) to the development of MaaS in Stockholm implies there may be a mismatch between the stakeholders active on the market and the issues or tasks which need to be addressed.

\subsection{Exploring the City of Stockholm's role}

Following up on Question 6, Question 7 asked respondents to indicate the degree to which they think the City of Stockholm should participate in the development of MaaS in Stockholm.

Of 24 responses, 20 indicated support for a medium-high level of engagement from the City administration. This may be interpreted as meaning various things. For example, it could mean the City is seen as doing too little and needs to be more engaged; or that (following up from Question 6) that the City can be less of a barrier, or create opportunities, through increased engagement. On the other hand, the result may indicate (as other results suggested), that respondents consider more stakeholders should be involved in development of MaaS in Stockholm and that the City, either because of for example its organisational capacity, resources or its de facto role in governing the City's space, should have a key role. Such questions are addressed by Question 8, in which respondents were asked to identify the issues they think the City of Stockholm should be addressing (Figure 5). 


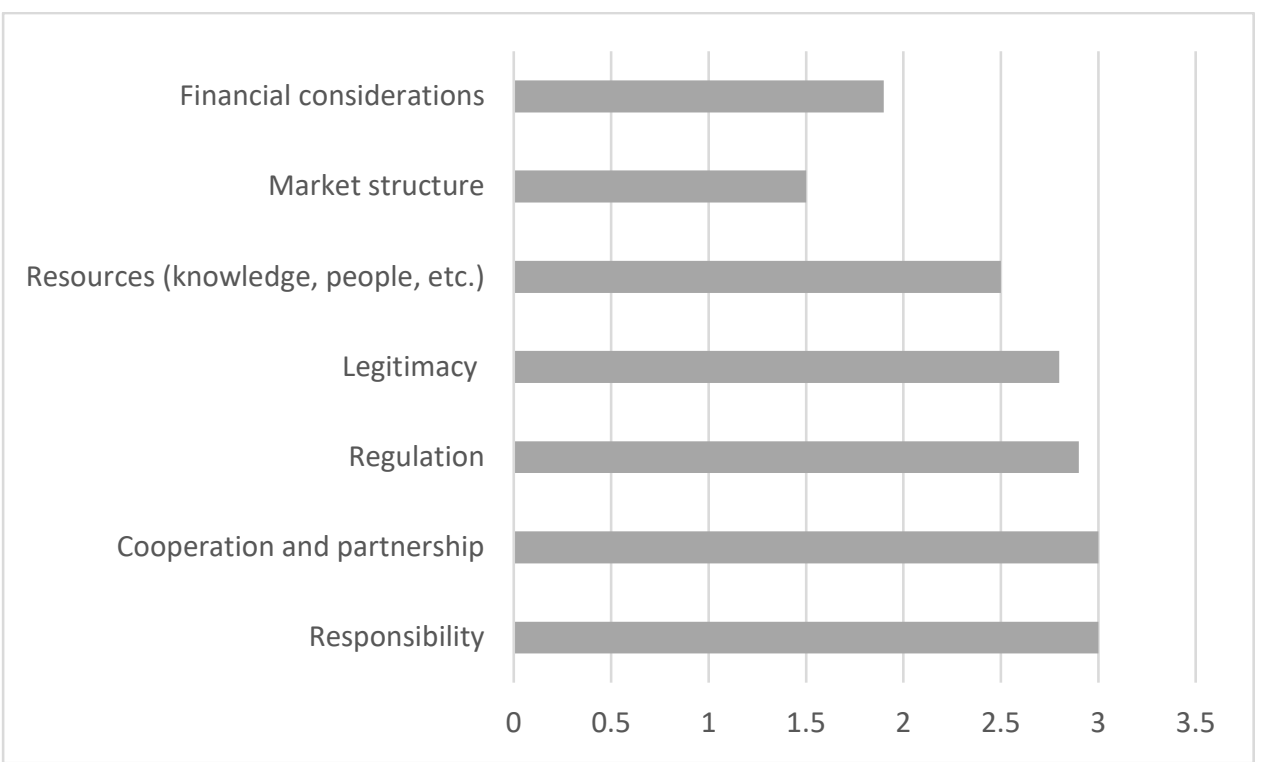

Figure 5. Responses to Question 8: "Which of these issues do you think the City of Stockholm should try to participate in and influence in the development of Combined Mobility / MaaS in Stockholm? (Scale of $0=$ No roles, $1=S$ mall role, $2=$ Moderate role, $3=$ large role, $4=$ Key role)

The responses to Question 8 indicate strong support for the City administration's involvement in developing cooperation and partnerships, ensuring responsibility for MaaS. The City administration is also viewed as having a significant role in establishing regulations and providing resources. There is a mixed range of responses regarding financial considerations, and respondents generally view the City as having a small role in determining the market structure. The pattern indicates a curious view of the City's role, with respondents hoping the City regulates MaaS whilst having a small role in the market structure and in influencing financial considerations.

\section{Discussion}

A key issue emerging from the survey results is the importance of cooperation and partnership in the development of MaaS in Stockholm. Linking back to the reviewed literature, Kanda et al. (2015) synthesized seven business concept components ("business aspects" in Table 1) and emphasised that public-private partnerships, market regulations and legitimacy have been particularly relevant for the development and diffusion of environmental technologies. This is informed by some characteristics of environmental technologies such as their complexity, the importance of financing, the need to adapt to different market types and also the need for collaboration between various societal actors and institutions. Partnerships and collaborations are deemed important in the diffusion and upscaling of environmental technologies because of their systemic nature which implies that different actors such as local governments and private companies have to collaborate and share value (see Tsvetkova and Gustafsson, 2012). In making a connection to the multi-level perspective, such partnerships and collaborations are not only needed between MaaS developers but also between such niche level actors and established actors who are embedded in the regime such as transport authorities, as they will be key actors to buy into and assist the scale up of MaaS beyond the niche (similar observations 
are made by institutional theory studies of MaaS such as Mukhtar-Dahlgren et al., 2016, Karlsson et al. 2020; cf. Smith et al, 2020).

As such, to facilitate the development of MaaS in Stockholm, there may be the need for intermediation activities which provide the necessary platforms for different stakeholders to collaborate. Indeed, the activities of the initiatives illustrated in Table 2 emphasise the establishment of on- and offline platforms to foster collaboration. Such boundary spanning activities have been discussed as particularly important for the generation and diffusion of environmental technologies since resources and competence need to be combined in different ways than in "conventional" innovations (Jakobsen and Clausen, 2016). However, our results indicate the presence of system level challenges, particularly concerning market structure and regulation. On the one hand, regulatory concerns seem to occupy a central role in the development of MaaS in Stockholm. On the other hand, neither stakeholders nor any of the local initiatives appear to be focusing on framing regulatory frameworks, or even more crucially, formulating a common definition. From a multi-level perspective these struggles can be characteristic of the emerging phases of such an innovation and thus will take time and effort before a coherent niche emerges with a set of rules, user practices, and markets. Until such a phase, the upscale of MaaS will be characterised by experiments and struggles to find common grounds between various actors. The MLP conceptualization of the transition to MaaS systems provides insights as to why such a change can be difficult and an essential issue for governance. Is it not simply an technological challenge but rather a challenge related to a dynamic set of actors, networks and institutions interacting with each other over-time.

This may have implications for the future development of MaaS in Stockholm. Regulation is emphasized since it is as an important factor in the diffusion of environmental innovations (cf. del Río et al., 2016). Regulations are different on different markets and can serve as drivers and obstacles in the upscaling of environmental innovations. Regulations also influence perceptions about legitimacy, which includes both public acceptance and compliance with key institutions and regulations. Innovations such as MaaS need legitimacy from relevant stakeholders such as customers, funders, policy makers for relevant resources (financing, human capital, policies) to be made available and also for customers apart from enthusiasts to buy into the innovation. Legitimation is not often a choice in itself but an outcome of several input choices and takes time to develop.

Strategies for legitimation include changing the rules, compliance with the rules, or influencing the creation of new institutional frameworks (Bergek et al., 2008; cf. the emergence of MaaS in Finland, LVM 2017). Characteristic of the early market development phases for environmental innovations, activities such as legitimation, prototyping and piloting contribute to the acceptance of environmental innovation as an important economic activity. The local initiatives illustrated in Table 2 are, by addressing different aspects and testing divergent approaches to MaaS, contributing in various ways towards building legitimacy for MaaS in Stockholm. This is understandable in the early market development phase, yet the absence of common definitions and regulations may generate barriers in the future.

Turning to the role of the City of Stockholm, our results indicate a high level of expectation from stakeholders. There is support for the active engagement of the City administration in developing cooperation and partnerships and building legitimacy, something that is already 
underway (see Table 2). However, the extent to which the City of Stockholm can be an active or passive participant depends in part on the tasks to be undertaken. Respondents identified the City administration as having an important role in establishing regulations and providing resources, yet each of these tasks may be difficult for the City to achieve due to the contextual factors described in Section 2.3. The City of Stockholm is just one of 26 municipalities in its region, and one of 290 in Sweden, meaning both regulations and resources may be required at the inter-municipal level (i.e. at the regional or national level) in addition to the intra-municipal level (i.e. staffing arrangements between municipal departments within the same local government).

In the early phases of market development, it may be possible to envisage small-scale pilot projects contained within single municipalities or regions, but large-scale market development is likely to, as suggested above, require regulations that all municipalities and stakeholders can utilise. Our results thus indicate that, although there is a role for local governments in the development of Maas, there is also a need for multi-level governance involving other levels of government. This raises the question of at which point regional or national levels of government should be involved in defining regulations for MaaS (cf. LVM 2017).

Local governments may be able to facilitate or participate in multi-stakeholder initiatives to establish MaaS platforms and move from roadmaps and action plans (see Table 2) to implementation; they may even, through for example creative use of local regulations, financial instruments, or participation in externally-financed projects, be able to allocate resources or offer incentives that support development of MaaS platforms (as observed in Stockholm within CIVITAS Eccentric). However, local governments are in most contexts unlikely to be able to define the regulatory system governing MaaS, nor provide capital for start-up of MaaS services (cf. Aaltonen, 2017). Indeed, the fact that few stakeholders are in a position to undertake these tasks provides a partial explanation as to why most stakeholders focus on other aspects, such as development of cooperation and partnerships. Thus, as Smith et al. (2005) argue, managing transitions (including transitions to MaaS) requires continuous adaptation in the prevailing system of governance to changing circumstances in order to articulate what needs to be done, related policy interventions, applying relevant resources and follow-up actions - similar to adaptive policy processes suggested by Jittrapirom, et al., (2018). Similarly, Loorbach (2010) highlights the need to undertake experiments, monitor and evaluate these experiments, and adjust the visions, expectations and collective goals. In this regard, the role of governance in transitions to Maas is to provide a both a normative and cognitive direction and deploy resources to that effect.

Finally, the main findings from our studies consolidates research findings on the development and implementation of MaaS that has been reported from studies in other cities. Specifically, formal and informal institutional barriers have been reported to influence the development and introduction of MaaS (Holmberg et al., 2016), while Polydoropoulou et al., (2019) identified several technical (e.g. ICT infrastructure), economic (increase market share) and social aspects (the attachment to the personal car) in the study of MaaS development in Budapest and Greater Manchester which have also been confirmed in our studies. 


\section{Conclusions}

The results of this study provide indications as to the type of barriers and opportunities that may impede or enable the development of MaaS in Stockholm and other cities. Cooperation and partnership are critical to the development and upscaling of environmental innovations, including MaaS, and current initiatives aiming to facilitate MaaS in Stockholm aim to strengthen interactions between stakeholders and identify steps forward towards implementation of MaaS. The City of Stockholm is active in such initiatives, and survey data suggests that the City administration should continue to play an active role in facilitating and supporting development of Maas.

Nevertheless, the survey data also indicates that the market structure, regulation and financial aspects will be critical challenges to development of MaaS. On such issues, single local governments may be able to use their mandate, resources or influence to facilitate development of local MaaS platforms or pilot projects, yet are unlikely to be able to tackle broader, trans-local multi-level challenges. Thus, whilst the survey data suggests support for the active engagement of local governments in the development of MaaS, it also implies other levels of government must contribute if diffusion and upscaling within and between contexts is to occur. Our findings point towards the need for further research, including interview studies and larger survey, to validate these findings at a larger scale and across contexts, along with policy studies of implemented Maas pilot projects to examine if and how barriers can be overcome to accelerate upscaling of MaaS. 


\section{Appendix}

\begin{tabular}{|c|c|c|}
\hline Survey Question & \multicolumn{2}{|l|}{ Answer Options } \\
\hline $\begin{array}{l}\text { 1. Which type of organization do } \\
\text { you work for? }\end{array}$ & \multicolumn{2}{|c|}{$\begin{array}{l}\text { - } \text { Company } \\
\text { - Government Department/Agency } \\
\text { - Municipality } \\
\text { - Research } \\
\text { - Other }\end{array}$} \\
\hline $\begin{array}{l}\text { 2. How large/small do you consider } \\
\text { your organisation's role in the } \\
\text { development of Combined } \\
\text { Mobility / MaaS in Stockholm? }\end{array}$ & \multicolumn{2}{|c|}{$\begin{array}{l}\text { - } \text { Don't know } \\
\text { - We have no role } \\
\text { - We have a little role } \\
\text { - Neither large or small } \\
\text { - We have a large role }\end{array}$} \\
\hline $\begin{array}{l}\text { 3. Do you consider that your } \\
\text { organisation plays an important } \\
\text { role in the development of } \\
\text { Combined Mobility / MaaS in } \\
\text { Stockholm? }\end{array}$ & \multicolumn{2}{|c|}{$\begin{array}{l}\text { - } \text { Don't know } \\
\text { - } \text { Unimportant role } \\
\text { - } \text { Sometimes important } \\
\text { - } \text { Often important } \\
\text { Key role }\end{array}$} \\
\hline $\begin{array}{l}\text { 4. Which of these issues do } \\
\text { you/your organisations work on } \\
\text { to Combined Mobility / MaaS in } \\
\text { Stockholm? }\end{array}$ & \multicolumn{2}{|c|}{$\begin{array}{ll}\text { - } & \text { Market structure } \\
\text { - } & \text { Regulation } \\
\text { - } & \text { Resouncial considerations } \\
\text { - } & \text { Cooperation and partnership } \\
\text { - } & \text { Responsibility } \\
\text { - Legitimacy }\end{array}$} \\
\hline $\begin{array}{l}\text { 5. Which of these issues do } \\
\text { you/your organisations consider } \\
\text { are important for the } \\
\text { development of Combined } \\
\text { Mobility / MaaS in Stockholm? }\end{array}$ & $\begin{array}{l}\text { - } \text { Never } \\
\text { - Sometimes } \\
\text { - Often } \\
\text { - Almost } \\
\text { - } \text { always } \\
\text { Only this }\end{array}$ & $\begin{array}{ll}\text { - } & \text { Market structure } \\
\text { - } & \text { Regulation } \\
\text { - } & \text { Financial } \\
& \text { considerations } \\
\text { - } & \text { Resources (e.g. } \\
& \text { knowledge, } \\
& \text { people etc) } \\
\text { - } & \text { Cooperation and } \\
& \text { partnership } \\
\text { - } & \text { Responsibility } \\
\text { - Legitimacy }\end{array}$ \\
\hline $\begin{array}{l}\text { 6. Do you consider... as a barrier to } \\
\text { or opportunity for the } \\
\text { development of Combined } \\
\text { Mobility / MaaS in Stockholm? }\end{array}$ & $\begin{array}{l}\text { - } \quad \text { Large barrier } \\
\text { - } \\
\text { oppither barrier or } \\
\text { - } \quad \text { Large } \\
\text { opportunity } \\
\text { - Small barrier } \\
\text { - Small } \\
\text { opportunity }\end{array}$ & $\begin{array}{ll}\text { - } & \text { Market structure } \\
\text { - } & \text { Infrastructure } \\
& \text { (physical) } \\
\text { - } & \text { Infrastructure } \\
& \text { (ICT) } \\
\text { - } & \text { Financial aspects } \\
\text { - } & \text { Institutional } \\
& \text { aspects }\end{array}$ \\
\hline
\end{tabular}




\begin{tabular}{|c|c|c|c|}
\hline & & & 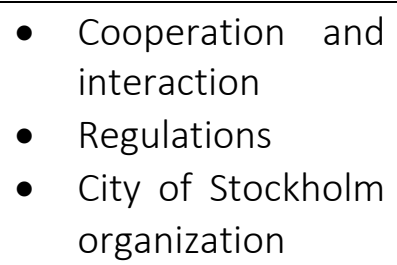 \\
\hline & $\begin{array}{l}\text { To what degree do you think the } \\
\text { City of Stockholm should } \\
\text { participate in the development } \\
\text { of Combined Mobility / MaaS in } \\
\text { Stockholm? }\end{array}$ & \multicolumn{2}{|l|}{$\begin{array}{ll}\text { - } & \text { Don't know } \\
\text { - } & \text { Not at all } \\
\text { - } & \text { Low } \\
\text { - } & \text { Medium } \\
\text { - } & \text { High }\end{array}$} \\
\hline & $\begin{array}{l}\text { Which of these issues do you } \\
\text { think the City of Stockholm } \\
\text { should try to participate in and } \\
\text { influence in the development of } \\
\text { Combined Mobility / MaaS in } \\
\text { Stockholm? }\end{array}$ & $\begin{array}{l}\text { - No role for the } \\
\text { city } \\
\text { - City has small } \\
\text { role } \\
\text { - Neither small or } \\
\text { large role-city } \\
\text { should } \\
\text { participate } \\
\text { - City has a large } \\
\text { role } \\
\text { City has a key } \\
\text { role }\end{array}$ & $\begin{array}{ll}\text { - } & \text { Market } \\
\text { - } & \text { Regulation } \\
\text { - } & \text { Financial } \\
& \text { considerations } \\
\text { - } & \text { Resources } \\
\text { (knowledge, } \\
\text { people) } \\
\text { - Cooperation } \\
\text { and } \\
\text { - } \text { partnership } \\
\text { - } \text { Lesponsibility } \\
\text { Legimacy }\end{array}$ \\
\hline & $\begin{array}{l}\text { What do you think will have } \\
\text { most influence on the } \\
\text { development of Combined } \\
\text { Mobility / MaaS in Stockholm? }\end{array}$ & \multicolumn{2}{|l|}{$\begin{array}{ll}\text { - } & \text { Technology } \\
\text { - } & \text { Adopters } \\
\text { - } & \text { Behavior } \\
\text { - } & \text { Other }\end{array}$} \\
\hline
\end{tabular}




\section{References}

Aaltonen, S. 2017. MaaS Readiness indicators for local authorities. Available at: https://civitas.eu/sites/default/files/maas_readiness_level_indicators_for_local_authorities_web.pdf (accessed 13 March 2019).

Aapaoja, A., Eckhardt, J., Nykänen, L., Sochor, J. 2017. MaaS service combinations for different geographical areas. Presented at the 24th World congress on intelligent transportation systems, Montreal, 29 October-2 November, 2017.

Akyelken, N., Banister, D., Givoni, M. 2018. The Sustainability of Shared Mobility in London: The Dilemma for Governance, Sustainability, 10, 420; doi:10.3390/su10020420

Beise, M., Rennings, K., 2005. Lead markets and regulation: a framework for analyzing the international diffusion of environmental innovations. Ecological Economics 52, 5-17.

Bergek, A., Jacobsson, S., Carlsson, B., Lindmark, S., Rickne, A., 2008. Analyzing the functional dynamics of technological innovation systems: A scheme of analysis. Research policy 37, 407-429.

Boons, F., Montalvo, C., Quist, J., Wagner, M., 2013. Sustainable innovation, business models and economic performance: an overview. Journal of Cleaner Production 45, 1-8.

Bryman, A., 2015. Social research methods. Oxford University Press, Oxford.

Callegati, F., Giallorenzo, S., Melis, A., Prandini, P., 2018. Cloud-of-Things meets Mobility-as-a-Service: An insider threat perspective, Computers \& Security, 74, 277-295.

Carrillo-Hermosilla, J., Del Río, P., Könnölä, T., 2010. Diversity of eco-innovations: Reflections from selected case studies. Journal of Cleaner Production 18, 1073-1083.

City of Stockholm. 2016. "Strategy for a fossil-fuel free Stockholm by 2040". Website:

www.stockholm.se/PageFiles/1311177/Strategy\%20for\%20a\%20fossil-

fuel\%20free\%20Stockholm\%20by\%202040.pdf (accessed 24 January 2019).

CIVITAS Eccentric, 2019. "Develop a smart choice of mobility services". Available at: https://civitas.eu/eccentric/stockholm (accessed 8 February 2019).

Del Rio, P., Peñasco, C., Romero-Jordán, D. 2016. What drives eco-innovators? A critical review of the empirical literature based on econometric methods. Journal of Cleaner Production, 112(4): 2158-2170

Docherty, I., Marsden, G., Anable, J. 2018. The governance of smart mobility. Transportation Research Part A: Policy and Practice, 115, 114-125.

Eckhardt, J., Aapaoja, A., Nykänen, L., Sochor, J. 2017. Mobility as a Service business and operator models. Presented at the 12th European congress on intelligent transportation systems, Strasbourg, 19-22 June, 2017.

Farla, J., Markard, J., Raven, R., Coenen, L. 2012. Sustainability transitions in the making: A closer look at actors, strategies and resources. Technological forecasting and social change, 79(6), 991-998. 
Fenton, P., Kanda, W., 2017. Barriers to the diffusion of renewable energy: studies of biogas for transport in two European cities, Journal of Environmental Planning and Management, 60:4, 725-742.

Finnveden, G., 2000. On the limitations of life cycle assessment and environmental systems analysis tools in general. The International Journal of Life Cycle Assessment, 5(4), 229.

Geels, F. W., 2011. The multi-level perspective on sustainability transitions: Responses to seven criticisms. Environmental innovation and societal transitions, 1(1), 24-40.

Haahtela, T., Viitamo, E., 2017. Searching for the potential of MaaS in commuting-comparison of survey and focus group methods and results. ICoMaaS 2017 proceedings (pp. 281-291).

Hensher, D. A. 2017. Future bus transport contracts under a mobility as a service (MaaS) regime in the digital age: Are they likely to change?. Transportation Research Part A: Policy and Practice, 98, 86-96.

Hirschhorn, F., Paulsson, A., Sørensen, C.H., Veeneman, W. 2020. Public transport regimes and mobility as a service: Governance approaches in Amsterdam, Birmingham, and Helsinki. Transportation Research Part A: Policy and Practice, 131: 178-191.

Holmberg, P.-E., Collado, M., Sarasini, S., Williander, M., 2016. Mobility as a service (MaaS): Describing the framework. Gothenburg: RISE Viktoria. Available at:

https://www.viktoria.se/sites/default/files/pub/www.viktoria.se/upload/publications/final_report_ma as_framework_v_1_0.pdf (2019-01-10)

Hrelja, R., Hjerpe, M., Storbjörk, S. 2015. "Creating Transformative Force? The Role of Spatial Planning in Climate Change Transitions Towards Sustainable Transportation." Journal of Environmental Policy and Planning 5: 1-19.

Hysing, E., Frändberg, L., Vilhelmson, B. 2015. "Compromising Sustainable Mobility? The Case of the Gothenburg Congestion Tax." Journal of Environmental Planning and Management 58 (6): 1058-1075.

International Transport Forum (ITF), 2015. "Winner | 2015 Promising Innovation in Transport Award (Passenger category)". Available at: http://2015.internationaltransportforum.org/awards (accessed 8 February 2019).

Isaksson, K., Antonson, H., Eriksson, L. 2017. Layering and parallel policy making - Complementary concepts for understanding implementation challenges related to sustainable mobility. Transport Policy, 53, 50-57.

Jakobsen, S. Høyvarde Clausen, T. 2016. Innovating for a greener future: the direct and indirect effects of firms' environmental objectives on the innovation process. Journal of Cleaner Production, 128(1): $131-141$.

Jittrapirom, P., Marchau, V., van der Heijden, R., Meurs, H. 2018. Dynamic adaptive policymaking for implementing Mobility-as-a Service (MaaS). Research in Transportation Business \& Management (in press).

Jittrapirom, P., Caiati, V., Feneri, A.-M., Ebrahimigharehbaghi, S., Alonso-González, M., Narayan, J. (2017). Mobility as a Service: A Critical Review of Definitions, Assessments of Schemes, and Key Challenges. Urban Planning, 2(2), 13-25. 
Karlsson, M., Sochor, J., Strömberg, H. 2016. Developing the "Service" in Mobility as a Service: experiences from a field trial of an innovative travel brokerage. Transportation Research Procedia 14, 3265-3273.

Karlsson, I.C.M., Mukhtar-Landgren, D., Smith, G., Koglin, T., Kronsell, A., Lund, E., Sarasini, S., Sochor, J. 2020. Development and implementation of Mobility-as-a-Service - A qualitative study of barriers and enabling factors. Transportation Research Part A: Policy and Practice, 131: 282-295.

Kamargianni, M., Li, W., Matyas, M., Schäfer, A. 2016 A critical review of new mobility services for urban transport. Transportation Research Procedia, 14: 3294 - 3303

Kamargianni, M., Matyas, M. 2017. The business ecosystem of mobility-as-a-service. In Transportation Research Board (Vol. 96). Transportation Research Board.

Kanda, W. 2017. Stimulating the diffusion of environmental technologies through export. Linköping: Linköping Studies in Science and Technology, Dissertations, No. 1864.

Kanda, W., Mejía-Dugand, S., Hjelm, O., 2015. Governmental export promotion initiatives: awareness, participation, and perceived effectiveness among Swedish environmental technology firms. Journal of Cleaner Production 98, 222-228.

Kanda, W., Sakao, T., Hjelm, O. 2016. Components of business concepts for the diffusion of large scaled environmental technology systems. Journal of Cleaner Production, 128, 156-167.

Kemp, R., Volpi, M., 2008. The diffusion of clean technologies: a review with suggestions for future diffusion analysis. Journal of Cleaner Production 16, 14-21.

Kemp, R., Schot, J., Hoogma, R. 1998. Regime shifts to sustainability through processes of niche formation: the approach of strategic niche management. Technology analysis \& strategic management, 10(2), 175-198.

Loorbach, D., 2010. Transition management for sustainable development: A prescriptive, complexity-based governance framework. Governance: An International Journal of Policy, Administration, and Institutions 23(1): 161-183.

LVM (Finnish Ministry of Transport and Communications), 2017. Act on Transport Services. Available at: https://www.Ivm.fi/en/-/act-on-transport-services-955864 (accessed 13 March 2019).

Mejía-Dugand, S., Hjelm, O., Baas, L., Rios, R.A. 2013. Lessons from the spread of Bus Rapid Transit in Latin America. Journal of Cleaner Production, 50: 82-90.

Melis, A., Mirri, S., Prandi, C. Prandini, M., Salomoni, P., Callegati, F. 2018. Integrating Personalized and Accessible Itineraries in MaaS Ecosystems Through Microservices. Mobile Networks and Applications, 23: 167-176.

Mignon, I., Bergek, A., 2016. System-and actor-level challenges for diffusion of renewable electricity technologies: an international comparison. Journal of Cleaner Production 128, 105-115.

Mukhtar-Landgren, D., Koglin, T., Kronsell, A. 2016. Institutional conditions for integrated mobility services (IMS): Towards a framework for analysis. K2-Sveriges nationella centrum för forskning och utbildning om kollektivtrafik. 
Mulley, C. 2017. Mobility as a Services (MaaS) - does it have critical mass?, Transport Reviews, 37:3, 247-251.

Pangbourne, K., Mladenovic. M, Stead. D, Milakis, D. 2020. Questioning Mobility as a Service: Unanticipated implications for society and governance. Transportation Research Part A: Policy and Practice, 131: 35-49.

Paulsson, A., Hylander, J., Hrelja, R., 2017. One for all, or all for oneself? Governance cultures in regional public transport planning, European Planning Studies, DOI: 10.1080/09654313.2017.1362376

Perez, L., S. Trüeb, H. Cowie, M.P. Keuken, P. Mudu, M.S. Ragettli, D.A. Sarigiannis, et al. 2015. Transport-Related Measures to Mitigate Climate Change in Basel, Switzerland: A Health-Effectiveness Comparison Study. Environment International 85: 111_119.

Polydoropoulou, A., Pagoni, I., Tsirimpa, A. 2019. Ready for Mobility as a Service? Insights from Stakeholders and End-users. Journal of Travel Behaviour and Society.

Polydoropoulou, A., Pagoni, I., Tsirimpa, A., Roumboutsos, A., Kamargianni, M., Tsouros, I., 2020. Prototype business models for Mobility-as-a-Service. Transportation Research Part A: Policy and Practice, 131: 149-162.

Rennings, K., 2000. Redefining innovation-eco-innovation research and the contribution from ecological economics. Ecological Economics 32, 319-332.

Rhodes, R. A. 2007. Understanding governance: Ten years on. Organization studies, 28(8), 1243-1264.

Rogers, E.M., 2003. Diffusion of innovations. The Free Press, Simon and Schuster, New York.

Samtrafiken, 2019. Swedish Mobility Program. Available at: https://samtrafiken.se/projekt/swedishmobility-program/ (accessed 8 February 2019).

Smith, A., Stirling, A., Berkhout, F., 2005. The governance of sustainable socio-technical transitions. Research Policy 34, 1491-1510.

Smith, A., Voß, J. P., Grin, J. 2010. Innovation studies and sustainability transitions: The allure of the multi-level perspective and its challenges. Research policy, 39(4), 435-448.

Smith, G., Sochor, J., Karlsson, M. 2018a. Mobility as a Service: Development scenarios and implications for public transport. Research in Transportation Economics, In Press, DOI: 10.1016/j.retrec.2018.04.001

Smith, G., Sochor, J., Karlsson, M. 2018b. Public-private innovation: barriers in the case of mobility as a service in West Sweden, Public Management Review, DOI: 10.1080/14719037.2018.1462399

Smith, G., Sochor, J., Karlsson, M. 2020. Intermediary MaaS Integrators: A case study on hopes and fears. Transportation Research Part A: Policy and Practice, 131: 163-177.

Strömberg, H., Rexfelt, O., Karlsson, M-A., Sochor, J. 2016. Trying on change - Trialability as a change moderator for sustainable travel behaviour. Travel Behaviour and Society, 4, 60-68.

Tsvetkova, A., Gustafsson, M. 2012. Business models for industrial ecosystems: a modular approach. Journal of Cleaner Production, 29: 246-254. 
van der Heijden, J., 2014. Governance for urban sustainability and resilience. Responding to climate change and the relevance of the built environment. Cheltenham: Edward Elgar Publishing Limited.

van Wee, B., and S. Handy. 2016. Key Research Themes on Urban Space, Scale, and Sustainable Urban Mobility. International Journal of Sustainable Transportation 10 (1): 18_24.

Verbong, G., Geels, F. W., Raven, R. 2008. Multi-niche analysis of dynamics and policies in Dutch renewable energy innovation journeys (1970-2006): hype-cycles, closed networks and technologyfocused learning. Technology Analysis \& Strategic Management, 20(5), 555-573.

Yin, R.K. 2009. Case study research: Design and methods, 4th Edition. Thousand Oaks, CA: Sage. 